\title{
RESPONS PETANI TERHADAP APLIKASI PUPUK ORGANIK CAIR RUMEN SAPI TERHADAP PERTUMBUHAN DAN PRODUKSI TANAMAN KAILAN (Brassica oleraceae Var. Acephala)
}

\section{Farmer's Response to Liquid Organic Fertilizer Application Cow Food on Growth and Production of Kailan Plant (Brassica oleraceae Var. Acephala)}

\author{
Vandalisna $^{1}$, Sugeng Mulyono², dan Budi Putra ${ }^{2}$ \\ ${ }^{1}$ Politeknik Pembangunan Pertanian Gowa \\ ${ }^{2}$ Balai Besar Pelatihan Pertanian Batangkaluku \\ e-mail: vandachaniago9@gmail.com
}

Received: 24 Maret 2020; Accepted: 20 April 2020; Published: 30 Juni 2020

\begin{abstract}
ABSTRAK
Penelitian ini bertujuan untuk mengetahui tingkat pengetahuan, sikap dan keterampilan petani dalam aplikasi pupuk organik cair terhadap pertumbuhan dan produksi tanaman kailan. Penelitian dilaksanakan di lokasi Kelompoktani Paraikatte Kelurahan Bontomanai, Kecamatan Bontomarannu, Kabupaten Gowa dari bulan April sampai dengan September 2018. Metode yang digunakan adalah pendekatan individu dan pendekatan kelompok dengan teknik diskusi dan demonstrasi cara. Materi penyuluhan yang disampaikan yaitu aplikasi pupuk organik cair terhadap pertumbuhan dan produksi tanaman kailan. Hasil penyuluhan yang diperoleh dari inovasi yang telah disampaikan dimana perubahan pengetahuan petani mencapai 398 atau 79,6\%, perubahan sikap sebesar 446 atau 89,2\% dan keterampilan 444 atau 88,8\% serta efektifitas hasil penyuluhan sebesar $71,15 \%$ berada pada tingkat efektif.
\end{abstract}

Kata kunci: POC, rumen sapi, kailan

\section{ABSTRACT}

This study aims to determine the level of knowledge, attitudes and skills of farmers in the application of liquid organic fertilizer to the growth and production of kailan plants. The research was conducted at the Paraikatte Kelompoktani location in Bontomanai Sub-district, Bontomarannu Subdistrict, Gowa Regency from April to September 2018. The method used was an individual approach and a group approach with discussion techniques and demonstration methods. The material presented was the application of liquid organic fertilizer to the growth and production of kailan plants. The results of counseling obtained from innovations that have been delivered where the change in knowledge of farmers reached 398 or $79.6 \%$, a change in attitude of 446 or $89.2 \%$, skills 444 or $88.8 \%$ and the effectiveness of extension results of $71.15 \%$ are at the level effective.

Keywords: POC, cow rumen, kailan

\section{PENDAHULUAN}

Teknologi sistem pertanian organik adalah sebagai bagian dari sistem pertanian berkelanjutan yang merupakan salah satu jawaban atas terjadinya degradasi lahan serta kelestarian lingkungan dan kesehatan manusia. Ketergantungan petani terhadap komponen revolusi hijau dan lunturnya kearifan-kearifan lokal pada diri petani adalah sangat penting untuk mendapatkan perhatian yang serius dalam mengatasi adanya permasalahan tersebut. Penggunaan pupuk kimia secara terus menerus akan menyebabkan kemampuan tanah

Diterbitkan Oleh, 
untuk mendukung ketersediaan hara dan kehidupan mikroorganisme dalam tanah menurun. Oleh karena itu jika tidak segera diatasi maka dalam jangka waktu tidak terlalu lama, lahan-lahan tersebut tidak mampu lagi berproduksi secara optimal dan berkelanjutan (I Wayan dan Ni Wayan, 2013) serta kesehatan manusia semakin terancam.

Menurut Prasetyo (2007), sistem pertanian organik di Indonesia masih merupakan gerakan yang sangat terbatas, yang belum mendapat dukungan sepenuhnya dari pihak pemerintah, peneliti maupun petani sehingga diperlukan langkah-langkah strategis untuk mengkombinasikan teknologi sistem pertanian organik kepada masyarakat petani. Selanjutnya dijelaskan oleh Kriswanto (2006) bahwa banyak sistem pertanian organik yang telah dihasilkan, tetapi cara untuk mengkomunikasikan kepada petani sangat susah karena memerlukan metodemetode khusus untuk mencapai hal tersebut. Hal ini karena kecendrungan masyarakat yang sangat tergantung pada penggunaan pupuk buatan masih sangat sulit untuk ditinggalkan.

Sayuran merupakan sumber esensial vitamin dan mineral, didalam sayuran mengandung vitamin A,B,C, zat kapur, dan zat besi yang diperlukan untuk pertumbuhan tulang, gigi dan memperlancar peredaran darah serta alat perencanaan. Dewasa ini kesadaran masyarakat akan pentingnya sayuran organik semakin meningkat, untuk itu peningkatan produksi sayuran organik perlu dilakukan, seperti tanaman kailan. Kailan adalah sayuran yang berdaun tebal, datar, mengkilap, berwarna hijau, dengan batang tebal dan sejumlah kecil kepala bunga berukuran kecil hampir vertigial mirip dengan bunga pada brokoli.

Ditinjau dari segi ekonomi dan bisnis kailan memiliki prospek yang cukup menawan untuk dibudidayakan sebagai sayuran untuk macam-macam masakan, kailan juga bisa dikonsumsi mentah sebagai lalapan karena batangnya memiliki rasa yang agak manis dan empuk serta daunnya sangat enak dan legit di lidah. Selain sebagai bahan sayuran yang mengandung zat gizi cukup lengkap, kailan sangat baik untuk kesehatan karena kaya vitamin A, kalsium dan zat besi (Sinaga, P, 2014). Produksi kailan yang tergolong tanaman kubis mengalami pasang surut. Pada tahun 1998 merupakan puncak produksi yaitu
1,45 ton dan terus menurun sampai tahun 2002 menjadi 1,23 ton dan meningkat kembali pada tahun 2008 mencapai 1,32 ton.

Tekait dengan masalah produksi sayuran, hal lain yang tidak kalah penting adalah pemberian pupuk. Pupuk merupakan bahan yang mengandung sejumlah nutrisi yang diperlukan bagi tanaman. Pemupukan adalah upaya pemberian nutrisi kepada tanaman guna menunjang kelangsungan hidupnya. Pupuk dapat dibuat dari bahan organik. Pemberian pupuk perlu memperhatikan takaran yang diperlukan oleh tumbuhan, jangan sampai pupuk yang digunakan kurang atau melebihi takaran yang akhirnya akan mengganggu pertumbuhan dan perkembangan tanaman. Pupuk dapat diberikan lewat tanah ataupun disemprotkan kedaun. Sejak dulu sampai saat ini pupuk organik diketahui banyak dimanfaatkan sebagai pupuk dalam sistem usaha tani oleh para petani (Sutedjo 2010).

Usaha untuk meningkatkan kuantitas dan kualitas tanaman kailan dapat diterapkan dengan menggunakan pupuk cair rumen sapi yang difermentasi. Kandungan nutrisi dan kandungan nitrogen isi rumen sapi cukup tinggi, hal ini disebabkan belum terserapnya zat-zat makanan yang terkandung didalamnya, sehingga zat-zatnya tidak jauh beda dengannya zat-zat makanan yang berasal dari bahan bakunya.

Utomo 2015 menyatakan bahwa unsur nitrogen diperoleh dari mikroorganisme yang terdapat dalam rumen sapi yaitu bakteri Lumbricus (bakteri asam laktat), mikroba ini menghidrolisis protein menjadi peptida dan asam amino yang selanjutnya didegradasi menjadi amoniak. Amoniak merupakan senyawa $\mathrm{N}$ utama yang dibebaskan dalam dekomposisi pupuk organik. Rahayu at, al (2013) kandungan nutrient yang terdapat pada isi rumen sapi meliputi air $(8,8 \%)$, protein kasar $(9,63 \%)$, lemak $(1,81 \%)$, serat kasar $(24,60 \%)$, bahan ektrat tanpa nitrogen $(38,40 \%)$, abu (16,76\%), kalsium (1,22\%) dan posfor $(0,29 \%)$. Kandungan nutrisi isi rumen dapat menyamai kandungan nutrisi rumput lapang yaitu protein kasar (8,20\%), lemak kasar $(1,44 \%)$, serat kasar $(31,7 \%)$, bahan ektrat tanpa nitrogen (44,2\%, abu $(14,5 \%)$, kalsium $(0,366 \%)$ dan fosfor $(0,230 \%)$

Budidaya kailan memerlukan bahan organik yang mengandung unsur hara makro dan mikro

Diterbitkan Oleh, 
bagi tanaman serta dapat melengkapi dan menambah ketersediaan bahan organik dalam tanah. Mengemburkan tanah, meningkatkan porositas, aerasi dan komposisi mikroorganisme tanah (Murbandono, 2000). Dengan menambahkan pupuk organik cair rumen sapi yang difermentasi, merupakan teknologi yang mudah, ramah lingkungan, berkelanjutan dan menguntungkan.

\section{METODE PENELITIAN}

\section{Waktu dan Tempat}

Penelitian dilaksanakan di kelompoktani paraikatte Kelurahan Bontomanai, Kecamatan Bontomarannu Kabupaten Gowa mulai bulan April sampai September 2018.

\section{Materi Penelitian}

Alat yang digunakan dalam penelitian ini adalah folder, kamera, kuesioner, dan Lembaran Persiapan Menyuluh (LPM) sebagai media persiapan penyuluhan sedangkan bahan bahan yang digunakan yaitu benih kailan, limbah rumen sapi, molases/gula pasir, EM-4 dan untuk kegiatan harian yaitu kertas HVS, pulpen, kertas koran dan spidol

\section{Metode}

Metode pengumpulan data terdiri dari data primer dan data sekunder. Data primer diperoleh dari hasil wawancara langsung responden dengan menggunakan daftar kuisioner dan observasi lapangan yaitu mengadakan pengamatan langsung ke lahan usahatani. Sedangkan data sekunder diperoleh dari instansi pemerintah dan instansi yang terkait untuk menunjang dan melengkapi data yang dibutuhkan dalam penelitian ini (Karlinger, 2004).

\section{Rancangan Penyuluhan}

Rancangan penyuluhan merupakan suatu alat bantu bagi penyuluh sebelum merencanakan penyuluhan dengan melihat pertimbangan berbagai aspek analisis kebutuhan, masalah, tujuan yang ingin dicapai, metode serta teknik penyuluhan yang akan digunakan agar proses transfer teknologi dapat diserap secara maksimal oleh sasaran.

\section{Materi}

Materi penyuluhan yang disampaikan adalah materi tentang pembuatan pupuk organik cair rumen sapi dan aplikasinya pada tanaman kailan.

2. Metode dan teknik

Metode penyuluhan yang digunakan dalam penerapan rancangan penyuluhan melalui metode pendekatan individu dan kelompok. Metoda pendekatan kelompok menggunakan teknik ceramah, diskusi, dan demonstrasi cara. Sedangkan metode pendekatan perorangan menggunakan teknik penyuluhan demonstrasi cara.

3. Media penyuluhan

Media yang digunakan dalam kegiatan penyuluhan diperlukan sebagai alat bantu seperti folder dan benda sesungguhnya. Hal ini dilakukan sebagai upaya untuk meyakinkan kepada petani dalam memanfaatkan rumen sapi menjadi pupuk organik cair, sehingga petani mau mengadopsi serta mengaplikasikannya.

4. Evaluasi Penyuluhan

Evaluasi dilakukan untuk mengukur tingkat pengetahuan, sikap dan keterampilan petani responden terhadap materi atau hasil kajian. Evaluasi dilakukan sebanyak dua kali yaitu evaluasi awal (pree test) dan evaluasi akhir (post test) Evaluasi awal dilakukan sebelum pelaksanaan penyuluhan untuk mengetahui seberapa besar pengetahuan, sikap dan keterampilan petani tentang materi yang akan disampaikan sedangkan evaluasi akhir dilakukan untuk mengetahui seberapa besar perubahan pengetahuan sikap dan keterampilan petani sesudah mengikuti kegiatan penyuluhan, evaluasi awal dilakukan pada saat awal kegiatan dengan metode perorangan berupa kunjungan rumah, Sementara evaluasi akhir dilakukan setelah penyuluhan kedua dengan metode kelompok. Jumlah responden yaitu 25 orang.

Alat instrumen evaluasi yang digunakan berupa pertanyaan (kuisioner). yang terdiri dari 5 pertanyaan pengetahuan, 5 pertanyaan sikap, dan 5 pertanyaan keterampilan. Penentuan jumlah responden 25 orang.

Tingkat pengetahuan, sikap dan keterampilan petani responden diukur dengan menggunakan Rating Scale atau skala nilai kemudian diolah dan ditabulasi dengan menggunakan garis Kontinuum (Padmowihardjo, 
2002) dengan rumus sebagai berikut:

Tkt. Pengetahuan $=\frac{\text { Jumlah jawaban yang diperoleh }}{\text { Nilai tertinggi yang dicapai }} \times 100 \%$

Efektifitas penyuluhan dapat dihitung dengan menggunakan rumus yaitu :

Efektifitas Penyuluhan (EP) $=\frac{P s-P r}{(\text { n.4.Q)-Pr }} 100 \%$.

Ket.: Ps = Tes akhir ( Post test)

$\operatorname{Pr}=$ Tes awal (Pree tes )

$\mathrm{N}=$ Jumlah respoden

4 = Nilai tertinggi

$\mathrm{Q}=$ Jumlah pertanyaan

Ps $-\operatorname{Pr}=$ Peningkatan pengetahuan

N.4.Q = Nilai kesenjangan

Maka kriteria prosentase efektifitas penyuluhan menurut Padmowihardjo (2002) yaitu 0-25\%= Kurang efektif; $26-50 \%=$ Cukup efekiif; $51-75 \%=$ Efektif; 76-100\%= Sangat efektif.

\section{HASIL DAN PEMBAHASAN}

\section{Karakteristik Petani Responden.}

Karakteristik petani responden menggambarkan tentang keadaan dari petani yang menjadi obyek pengamatan baik dari segi umur pendidikan, pengalaman bertani, tanggungan keluarga.

1. Umur petani

Umur sangat menentukan dalam menerima dan menerapkan suatu inovasi dan teknologi baru dalam berusahatani. Adapun umur petani responden dapat dilihat pada Tabel 1. Tabel 1 Tingkat umur di Kelompoktani Paraikatte menunjukkan bahwa umur 31-40 tahun sebanyak 11 orang atau $44 \%$ dan umur 41-50 tahun sebanyak 7 orang atau $28 \%$, terlihat pula bahwa potensi tenaga kerja cukup besar pada usia produktif di Kelompoktani Paraikatte. (Maulana. A. Z, 2016)

Tabel 1. Tingkat umur petani responden di Kelompoktani Paraikatte Kelurahan Bontomanai Kecamatan Bontomarannu Kabupaten Gowa

\begin{tabular}{lccc}
\hline No. & $\begin{array}{c}\text { Tingkat Umur } \\
\text { (Tahun) }\end{array}$ & $\begin{array}{c}\text { Jumlah } \\
\text { (Orang) }\end{array}$ & $\begin{array}{c}\text { Persentase } \\
(\%)\end{array}$ \\
\hline 1 & $31-40$ & 11 & 44,00 \\
2 & $41-50$ & 7 & 28,00 \\
3 & $51-60$ & 3 & 12,00 \\
4 & $>61$ & 4 & 16,00 \\
\hline & Jumlah & 25 & 100,00 \\
\hline
\end{tabular}

2. Tingkat pendidikan

Pendidikan merupakan salah satu indikator untuk merubah pola fikir setiap individu. Semakin tinggi pendidikan maka tingkat adopsi suatu teknologi akan meningkat, tetapi semakin rendah pendidikan tingkat adopsi juga akan rendah pula. Namun petani yang berpendidikan rendah tetapi sering mendapatkan informasi penyuluhan, maka kemampuan berfikir untuk menerima suatu inovasi didukung dengan pengalaman berusaha tani dapat meningkatkan pengetahuan dalam mengelolah sumberdaya alam yang tersedia, sebagaimana tercantum pada Tabel 2. Tabel 2, Tingkat pendidikan di Kelompoktani Paraikatte menunjukkan bahwa tidak sekolah sebanyak 3 orang atau $12 \%$, SD 5 orang atau 20\%, SLTP 2 orang atau $8 \%$, dan SLTA sebanyak 15 orang atau $60 \%$. Dengan demikian semakin tinggi pendidikan akan mempengaruhi pengambilan keputusan dalam kegiatan mengelola usahataninya (Dewi dan Sudiarti, 2005)

Diterbitkan Oleh, 
Tabel 2. Tingkat Pendidikan Petani Responden di Kelompoktani Paraikatte Kelurahan Bontomanai Kecamatan Bontomarannu Kabupaten Gowa

\begin{tabular}{cccc}
\hline No. & $\begin{array}{c}\text { Tingkat } \\
\text { Pendidikan }\end{array}$ & $\begin{array}{c}\text { Jumlah } \\
\text { (Orang) }\end{array}$ & $\begin{array}{c}\text { Persentase } \\
(\%)\end{array}$ \\
\hline 1 & Tidak Sekolah & 3 & 12,00 \\
2 & SD & 5 & 20,00 \\
3 & SLTP & 2 & 8,00 \\
4 & SLTA & 15 & 60,00 \\
\hline & Jumlah & 25 & 100,00 \\
\hline
\end{tabular}

3. Tanggungan keluarga.

Tanggungan keluarga responden berdasarkan jumlah anggota keluarga dibagi menjadi dua terdiri dari 1-4 orang dan 5-8 orang dapat dilihat pada Tabel 3. Tabel 3 diatas menunjukkan bahwa petani yang paling banyak memiliki tanggungan keluarga 1-4 orang sebanyak $13 \mathrm{KK}$ atau $52 \%$, dan 5-8 orang sebanyak $12 \mathrm{KK}$ atau $48 \%$. Dengan demikian tanggungan keluarga merupakan salah satu faktor penyebab wanita secara sukarela mengambil keputusan untuk keluar dari rumah bekerja mendapatkan pendapatan lebih bagi keluarga agar kebutuhan hidup keluarganya terpenuhi (Shamsiah 2002).

Tabel 3. Tanggungan Keluarga Petani Responden di Kelompoktani Paraikatte Kelurahan Bontomanai Kecamatan Bontomarannu Kabupaten Gowa

\begin{tabular}{cccc}
\hline No. & $\begin{array}{c}\text { Jumlah Tanggungan } \\
\text { Keluarga (orang) }\end{array}$ & $\begin{array}{c}\text { Jumlah } \\
\text { (orang) }\end{array}$ & $\begin{array}{c}\text { Persentase } \\
(\%)\end{array}$ \\
\hline 1 & $1-4$ & 13 & 52,00 \\
2 & $5-8$ & 12 & 48,00 \\
\hline & Jumlah & 25 & 100,00 \\
\hline
\end{tabular}

Tabel 4. Pengalaman Berusahatani Petani Responden di Kelompoktani Paraikatte Kelurahan Bontomanai Kecamatan Bontomarannu Kabupaten Gowa

\begin{tabular}{cccc}
\hline No. & $\begin{array}{c}\text { Pengalaman Berusahatani } \\
(\text { Thn })\end{array}$ & $\begin{array}{c}\text { Jumlah } \\
\text { (orang) }\end{array}$ & $\begin{array}{c}\text { Persentase } \\
(\%)\end{array}$ \\
\hline 1 & $0-5$ & 4 & 16,00 \\
2 & $6-10$ & 3 & 12,00 \\
3 & $11-15$ & 3 & 12,00 \\
4 & $>16$ & 15 & 60,00 \\
\hline & Jumlah & 25 & 100,00 \\
\hline
\end{tabular}

4. Pengalaman berusahatani

Pengalaman petani sangat beragam yaitu $0-5$ tahun, 6-10 tahun, 11-15 tahun dan 16 tahun keatas. Untuk jelasnya dapat dilihat pada Tabel 4. Tabel 4 Pengalaman berusahatani di kelompoktani Paraikatte menunjukkan bahwa 0-5 tahun sebanyak 4 orang atau $16 \%$, 6-10 tahun 3 orang atau 12\%, 11-15 tahun 3 orang atau $12 \%$, dan $\geq 16$ tahun sebanyak 15 orang atau $60 \%$. Dengan demikian pengalaman berusahatani yang cukup lama menjadikan petani lebih matang dan lebih berhati-hari, dalam mengambil keputusan terhadap usahataninya. Kegagalan dimasa lalu dapat dijadikan pelajaran sehingga ia lebih berhati-hati dalam bertindak. 
Sedangkan petani yang kurang berpengalaman umumnya lebih cepat dalam mengambil keputusan karena lebih berani menanggung resiko (Soekartawi, 2003).

\section{Respons Petani Terhadap Kajian Materi}

1. Pengetahuan

Hasil evaluasi awal diperoleh tingkat pengetahuan sebagai berikut :
Jumlah skor yang dipeoleh 249

Jumlah skor tertinggi $\quad=25 \times 5 \times 4=500$

Jumlah Skor terendah $\quad=25 \times 5 \times 1=125$

Tingkat pengetahuan awal responden adalah : $249 / 500 \times 100 \%=49,8 \%$.

Jika digambarkan dengan garis kontinuum akan terlihat seperti pada Gambar 1.

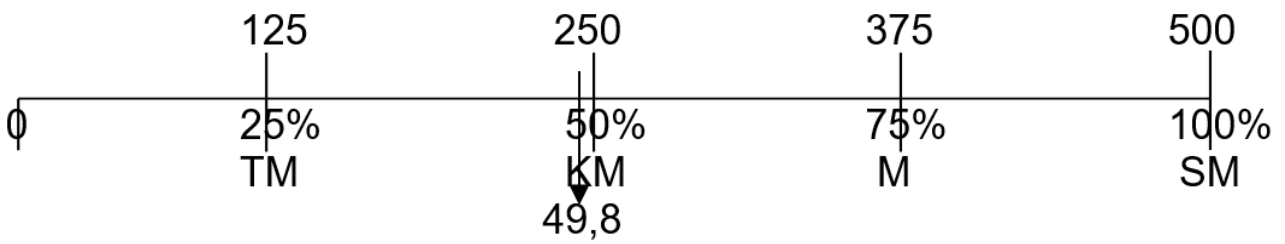

Gambar 1. Garis Continuum Evaluasi Awal

Gambar 1. menujukkan hasil evaluasi awal tingkat pengetahuan petani berada pada kategori kurang mengetahui dengan total nilai yang diperoleh sebesar 249 atau 49,8\% sedangkan hasil evaluasi akhir diperoleh nilai sebagai berikut: Jumlah skor yang dipeoleh 398 $\begin{array}{ll}\text { Jumlah skor tertinggi } & =25 \times 5 \times 4=500 \\ \text { Jumlah Skor terendah } & =25 \times 5 \times 1=125\end{array}$

Tingkat pengetahuan akhir responden adalah : $398 / 500 \times 100 \%=79,6 \%$.

Jika digambarkan dengan garis kontinuum akan terlihat seperti pada Gambar 2.

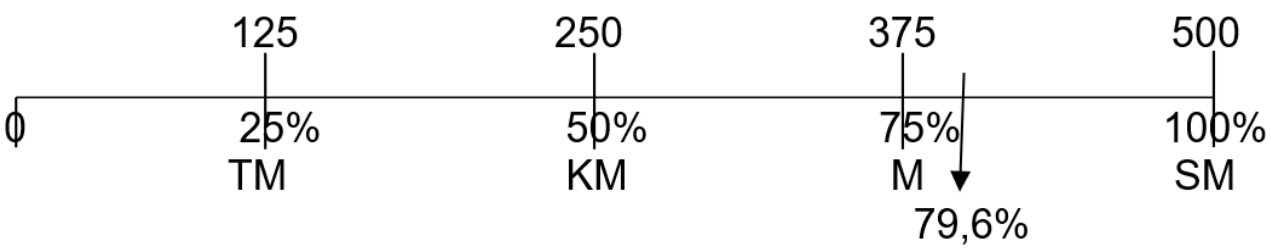

Gambar 2. Garis Continuum Evaluasi Akhir

Garis kontinuum diatas menujukkan bahwa tingkat pengetahuan petani berada pada kategori Sangat Mengetahui (SM) dengan total nilai yang diperoleh sebesar 398 atau 79,6\%. Hal ini menujukkan bahwa terjadi peningkatan pengetahuan petani tentang teknologi tentang pembuatan pupuk organik cair

2. sikap

Hasil evaluasi awal aspek sikap diperoleh sebagai berikut :

Jumlah skor yang dipeoleh 270

Jumlah skor tertinggi $\quad=25 \times 5 \times 4=500$

Jumlah Skor terendah $\quad=25 \times 5 \times 1=125$

Sikap awal responden adalah : 270/500x100\% = $54,0 \%$. Jika digambarkan dengan garis kontinuum akan terlihat seperti pada Gambar 3.

Sikap petani berada pada kategori Setuju (S) dengan total nilai yang diperoleh sebesar 270 atau 54\%. Hal ini menujukan bahwa petani setuju adanya pembuatan pupuk organik cair yang dikembangkan di kelompoktani paraikatte sedangkan hasil evaluasi akhir diperoleh nilai sebagai berikut:

Jumlah skor yang diperoleh 446

Jumlah skor tertinggi $\quad=25 \times 5 \times 4=500$

Jumlah Skor terendah $\quad=25 \times 5 \times 1=125$

Sikap akhir responden adalah : 446/500x100\% = $89,2 \%$. Jika digambarkan dengan garis kontinuum akan terlihat seperti pada Gambar 4. 


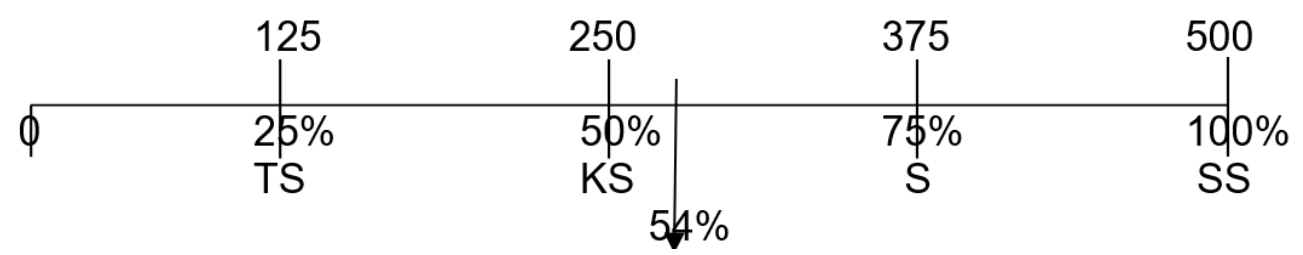

Gambar 3. Garis Continuum Evaluasi Awal

Jika digambarkan dengan garis Continuum adalah sebagai berikut:

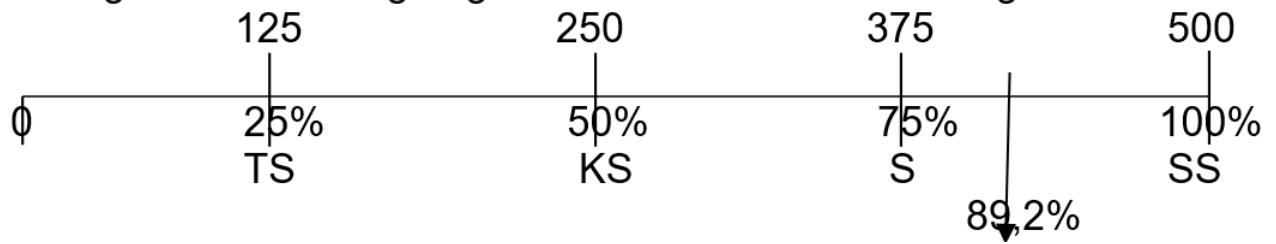

Gambar 4. Garis Continuum Evaluasi Akhir

Sikap petani berada pada kategori Sangat Setuju (SS) dengan total nilai yang diperoleh sebesar 446 atau 89,2\%. Hal ini menujukan bahwa petani sangat setuju adanya pembuatan pupuk organik cair yang dikembangkan di kelompoktani paraikatte.

3. Keterampilan

Hasil evaluasi awal keterampilan diperoleh sebagai berikut :

Jumlah skor yang dipeoleh 246

Jumlah skor tertinggi $\quad=25 \times 5 \times 4=500$

Jumlah Skor terendah $\quad=25 \times 5 \times 1=125$

Sikap awal responden adalah : 246/500x100\% = 49,2\%. Jika digambarkan dengan garis kontinuum akan terlihat seperti pada Gambar 5.
Hasil evaluasi sebelum diadakan penyuluhan menujukan bahwa tingkat keterampilan petani responden mencapai 246 atau 49,2\%, berada pada kategori Kurang Terampil (KT) sedangkan hasil evaluasi akhir keterampilan diperoleh nilai sebagai berikut:

Jumlah skor yang diperoleh 444

Jumlah skor tertinggi $\quad=25 \times 5 \times 4=500$

Jumlah Skor terendah $\quad=25 \times 5 \times 1=125$

Sikap akhir responden adalah : 444/500x100\% = $88,8 \%$. Jika digambarkan dengan garis kontinuum akan terlihat seperti pada Gambar 6. Garis cuntinuum tersebut menujukkan bahwa setelah penyuluhan dilakukan, keterampilan petani tentang pembuatan pupuk organik cair berada pada skor 444 atau 88,8\% yang berarti Sangat Terampil (ST).

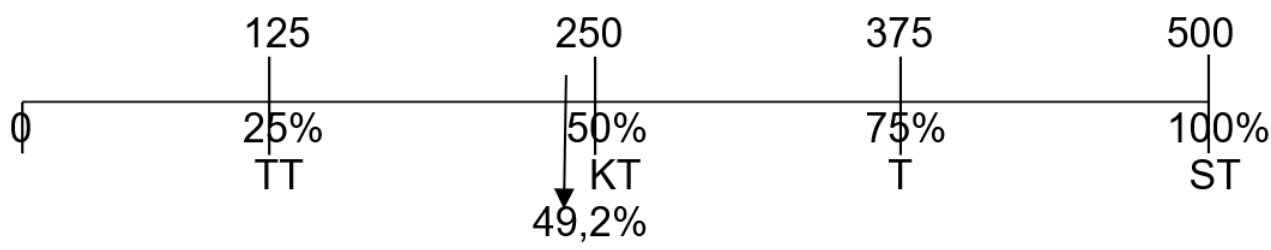

Gambar 5. Garis Continuum Evaluasi Awal

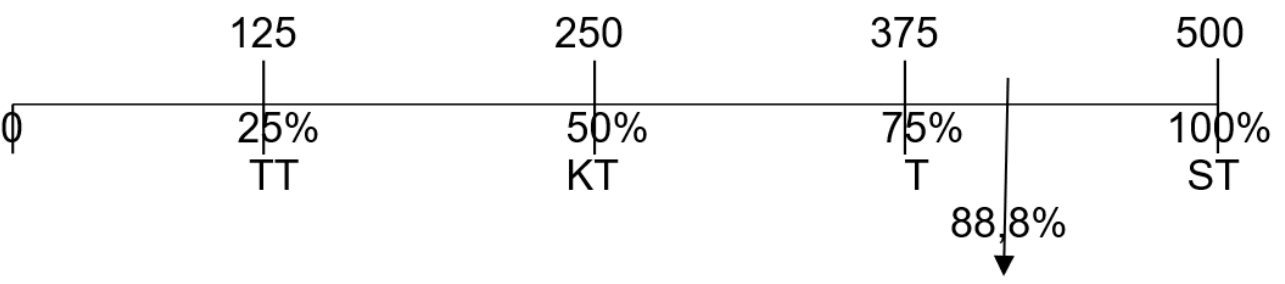

Gambar 6. Garis Continuum Evaluasi Akhir

Diterbitkan Oleh, 
Hasil evaluasi awal dan evaluasi akhir ditabulasikan untuk mengevaluasi tingkat pengetahuan, sikap dan keterampilan responden berdasarkan kategori nilai yang dicapai. Hasil rekapitulasi digunakan untuk mengetahui perubahan perolehan nilai persentase dan nilai maksimum pada tingkat pengetahuan, sikap dan keterampilan. Hasil rekapitulasi dapat dilihat pada Tabel 5.

Tabel 5. Rata-Rata Tingkat Perubahan Pengetahuan, Sikap dan Keterampilan Responden.

\begin{tabular}{lccccccc}
\hline \multirow{2}{*}{ Deskripsi } & \multirow{5}{*}{ Nilai yang diperoleh } & \multirow{2}{*}{ Perubahan } \\
\cline { 3 - 7 } & \multirow{2}{*}{ Nilai Maksimal } & \multicolumn{5}{c}{ Evaluasi } & \\
\cline { 3 - 7 } & & Awal & $\%$ & Akhir & $\%$ & Nilai & $\%$ \\
\hline Pengetahuan & 500 & 249 & 49,8 & 398 & 79,6 & 149 & 29,8 \\
Sikap & 500 & 270 & 54 & 446 & 89,2 & 176 & 35,2 \\
Keterampilan & 500 & 246 & 49,2 & 444 & 88,8 & 198 & 39,6 \\
\hline Jumlah & 1.500 & 765 & & 1288 & & 523 & \\
\hline
\end{tabular}

\section{Efektivitas penyuluhan}

Evaluasi penyuluhan dilakukan bertujuan untuk mengetahui peningkatan pengetahuan, sikap dan keterampilan responden dengan membandingkan hasil ealuasi awal dan evaluasi akhir. Evaluasitersebut dapat dilihat dari perhitngan efektifitas penyuluhan sebagai berikut :

$$
\begin{aligned}
& \text { Evektifitas Penyuluhan }=\frac{\text { Ps }- \text { Pr }}{-----x_{100 \%}} \\
& =\frac{1288-765}{----------x} 100 \% \\
& 523 \\
& =\quad------------x 100 \% \\
& =71,16 \%
\end{aligned}
$$

Berdasarkan kriteria penilaian maka kegiatan penyuluhan yang telah dilaksanakan termasuk dalam kategori efektif dengan nilai 71 , $16 \%$

\section{KESIMPULAN}

Hasil penyuluhan yang diperoleh dari inovasi yang telah disampaikan dimana perubahan pengetahuan petani mencapai 398 atau $79,6 \%$, perubahan sikap sebesar 446 atau $89,2 \%$ dan keterampilan 444 atau 88,8\% serta efektifitas hasil penyuluhan sebesar $71,15 \%$ (efektif).

\section{DAFTAR PUSTAKA}

Dewi, K.R. dan Sudiarti. 2005. Faktor Sosial Ekonomi Yang Mempengaruhi Pengambilan Keputusan Petani dalam Sistem Penjualan Sayuran. Jurusan Sosial Ekonomi Pertanian Fakultas Pertanian Universitas Udayana. Denpasar.

I Wayan dan NI Wayan, 2013. Analisis Kuliatas Larutan MOL (Mikroorganisme lokal) Berbasis Daun Gamal (Gliricidia sepium). Denpasar : Universitas Udayana. E-Jurnal Agroekoteknologi Tropika ISSN : 23016515 Vol 2 No 2, 2013, E-ISSN. 2338-1787.

Kerlinger, 2004. Asas-Asas Penelitian Behavioral (Terjemahan L.R. Simatupang. Gajah Mada Universitas Press, Yokyakarta.

Kriswanto (2006). Mewaspadai Revolusi Hijau II. Diakses 6 Maret 2008 Pada Situs http://nasih.staff.ugm.ac.id.

Maulana Adam. Z 2016. Kelompok Usia Produktif Kunci Majunya Indonesia, on line (we are indostudents, bolg spot.co.id), Diakses Tanggal 5 April 2018.

Murbandono, 2000. Manfaat Bahan Organik bagi tanaman. Puslit Biologi, LIPI, Bogor, Hal 19-23.

Padmowihardjo, S, 2002. Evaluasi Penyuluhan Pertanian, Modul Universitas Terbuka. Jakarta.

2002. Metode dan Teknik Penyuluhan Pertanian. Universitas Terbuka. Jakarta.

Prasetyo, 2007. Pertanian Organik Merupakan Gerakan Bawah Tanah Petani Indonesia

Diterbitkan Oleh, 
Melawan Revolusi Hijau. (Diakses 6 Maret 2008. Pada Situs http://www.sinarharapan.co.id/berita/031 0/27/ipt02.html.)

Shamsiah. 2002. Dilema Wanita Berkahwin Berkerjaya: Suatu Perbincangan Menurut Syariah.Http://ikim .gov.my/v5/index.php?lg=1\&opt=com arti cle $\&$ grp $=2 \& \mathrm{sec}=\& \mathrm{key}=713 \& \mathrm{cmd}=$ resetal 1(wanita).Diakses pada tanggal 5 April 2018.

Sinaga, P. 2014. Respon Pertumbuhan dan Produksi Kailan (Brassica oleraceae L.) pada Pemberian Pupuk Anorganik dan Berbagai Pupuk Organik Cair Paitan (Tithonia diversifalia(Hensl.)Gray). Universitas Sumatra Utara Medan.

Soekartawi,2003. Analisis Usaha Tani. Universitas Indonesia Press Jakarta.

Sutedjo, Mulyani. 2010. Pupuk dan cara pemupukan. Jakarta: Rineka Cipta..

Utomo.,A.,R.,P, 2015 Pemanfaatan kulit kacang tanah dan rumen sapi untuk pembuatan pupuk organik cair dengan penambahan jamur trichoderma (Trichoderma sp). Surakarta.

Diterbitkan Oleh, 